\title{
Effect of nanosilicon dioxide on growth performance, egg quality, liver histopathology and concentration of calcium, phosphorus and silicon in egg, liver and bone in laying quails
}

\author{
Samira Faryadi ${ }^{1} \cdot$ Ardashir Sheikhahmadi $^{1}$
}

Received: 29 July 2017/ Accepted: 12 October 2017/Published online: 20 October 2017

(c) The Author(s) 2017. This article is an open access publication

\begin{abstract}
This experiment was conducted to evaluate the effects of different levels of nanosilicon dioxide $\left(\mathrm{nSiO}_{2}\right)$ on performance, egg quality, liver histopathology and concentration of calcium $(\mathrm{Ca})$, phosphorus and silicon $(\mathrm{Si})$ in egg, liver and bone in laying quails. The experiment was administered using 60 laying quails at 16-26 weeks of age with five treatments [0 (control), 500, 1000, 2000 and $4000 \mathrm{mg} \mathrm{nSiO} 2$ per $\mathrm{kg}$ of diet] and four replicates in a completely randomized design. During the experiment, the amount of feed intake was recorded weekly and performance parameters were measured. During the last 3 days of the experiment, all of the eggs in each replicate were collected and egg quality parameters were measured. At the end of 26 weeks of age, the birds were sacrificed and blood samples were collected. Liver samples from each treatment were fixed in $10 \%$ buffered formalin for histopathological assessment. The right thigh bone and a portion of liver were inserted in plastic bags and stored at -20 . The results showed that $\mathrm{nSiO}_{2}$ supplementation significantly affected egg weight and egg mass $(P<0.05)$. Also, dietary $\mathrm{nSiO}_{2}$ supplementation decreased the yolk weight and increased the shell weight $(P<0.05)$. Moreover, $\mathrm{nSiO}_{2}$ increased bone ash content, $\mathrm{Ca}$ and $\mathrm{Si}$ concentration in the bone $(P<0.05)$. The liver enzymes in plasma and the liver tissue histopathology were not significantly affected $(P>0.05)$ by dietary treatments. In conclusion, the results indicated that dietary supplementa-
\end{abstract}

Ardashir Sheikhahmadi

a.sheikhahmadi@uok.ac.ir

1 Department of Animal Science, Faculty of Agriculture, University of Kurdistan, Sanandaj 66177-15175, Iran tion of $\mathrm{nSiO}_{2}$ could improve bone density and performance without any adverse effect on the health of laying quails.

Keywords Nanosilicon dioxide · Performance · Tissues minerals · Laying quails

\section{Introduction}

Silicon ( $\mathrm{Si}$ ) is the second abundant element in the earth's crust. This element exists in all body tissues, but it shows highest concentration in bone, skin, hair, nails and arteries (Jugdaohsingh 2007), and it is one of the essential elements for bone formation (Carlisle 1981; Nielsen and Sandstead 1974). It has been shown that $\mathrm{Si}$ supplementation in animals and humans increases bone mineral density and improves bone strength (Price et al. 2013). The deficiency of Si causes growth retardation, atrophy of organs, bone formation disorders, inflammation of the mucosa and of the skin in mammalian species (Bodak et al. 1997).

During the last few years, nanotechnology has been revealed as a fundamental approach in animal nutrition and especially in mineral nutrition. Nanoparticle is an expression used for particles with at least one dimension of $100 \mathrm{~nm}$ or less and represents an intermediate supramolecular state of matter (Maynard and Kuempel 2005). It is well known that due to high surface area and nanoscale size, nanoparticles possess unique physical and chemical properties (Sun et al. 2011).

Several studies have been conducted to evaluate the effects of silicate minerals on the performance and health of the poultry (Safaeikatouli et al. 2012). Tauqir et al. (2001) and Santurio et al. (1999) reported that poultry performance was improved with the use of silicate minerals in broiler diets. In turkeys, body weight gain and feed 
conversion ratio (FCR) significantly improved with dietary Si dioxide supplementation (Tran et al. 2015). In a study conducted by Carlisle (1972) the average daily weight gain for roosters fed with $100 \mathrm{mg}$ of sodium meta-silicate for 25 days was 2.57 and $3.85 \mathrm{~g}$ in control and treatment groups, respectively. It has been proposed that silicate minerals increase digestibility of diet and performance in broilers via gastrointestinal tract stimulation (Safaeikatouli et al. 2012). The most important silicate minerals, which are used in poultry diets, are kaolin, bentonite and zeolite. Various studies have demonstrated that sodium zeolite-A improved eggshell quality and bone strength (poultry and horse), enhanced tibia ash and decreased the incidence and severity of tibial dyschondroplasia in broilers fed diets with low levels of calcium (Ca) (Rabon et al. 1995). It is proposed that the beneficial effects of sodium zeolite-A on bone strength and eggshell might be related to its crystal structure or amounts of its $\mathrm{Si}$ or aluminum which affect $\mathrm{Ca}$ metabolism (Rabon et al. 1995). Therefore, we hypothesized that using $\mathrm{Si}$ in the form of nanoparticle increased its positive effects on the eggshell quality and performance of laying quails. Moreover, concentrations of $\mathrm{Ca}$, phosphorus (P) and Si minerals in egg, liver and bone of laying quails have been investigated.

\section{Materials and methods}

\section{Birds, management and treatments}

All procedures used in this study were approved by the guidelines of the Animal Ethics Committee of the University of Kurdistan. A total of hundred 16-week-old laying Japanese quails (Coturnix coturnix Japonica) were obtained from a local supplier. The obvious runts and birds in extreme weights were eliminated within the first 2 weeks which was considered as adaptation period. At 18 weeks of age, 60 clinically healthy birds were selected and randomly distributed between 20 cages $(20 \times 20 \mathrm{~cm}$; three birds per unit), with almost same average body weight $(263 \pm 8.9 \mathrm{~g})$ and egg production rate $(87.1 \pm 2.22 \%)$ throughout the cages.

The birds were fed either a control diet without $\mathrm{nSiO}_{2}$ addition, or diets containing 500, 1000, 2000, and $4000 \mathrm{mg}$ $\mathrm{nSiO}_{2} / \mathrm{kg}$ of diet until termination of the experiment. Four replicates were randomly assigned to each of the five dietary treatments. Feed (Table 1) and water were offered ad libitum. Light was provided for $16 \mathrm{~h}$ daily and temperature was maintained at $20 \pm 2{ }^{\circ} \mathrm{C}$ throughout the experiment.

Table 1 Ingredients and nutrients composition of the experimental diets (\% or as noted)

\begin{tabular}{|c|c|c|c|c|c|}
\hline \multirow[t]{2}{*}{ Item (\% or as noted) } & \multicolumn{5}{|c|}{ Supplemented nanosilicon dioxide level (mg/kg) } \\
\hline & 0 & 500 & 1000 & 2000 & 4000 \\
\hline \multicolumn{6}{|l|}{ Ingredients } \\
\hline Corn & 53.17 & 53.07 & 52.96 & 52.75 & 52.33 \\
\hline Soybean meal (44\% CP) & 35.00 & 35.02 & 35.04 & 35.08 & 35.16 \\
\hline Soybean oil & 5.43 & 5.43 & 5.43 & 5.43 & 5.43 \\
\hline Limestone & 3.79 & 3.82 & 3.86 & 3.93 & 4.06 \\
\hline Nanosilicon dioxide & - & 0.05 & 0.10 & 0.20 & 0.40 \\
\hline Dicalcium phosphate & 1.63 & 1.63 & 1.63 & 1.63 & 1.63 \\
\hline Sodium chloride & 0.34 & 0.34 & 0.34 & 0.34 & 0.34 \\
\hline Vitamin-mineral premix ${ }^{\mathrm{a}}$ & 0.50 & 0.50 & 0.50 & 0.50 & 0.50 \\
\hline DL-Methionine & 0.14 & 0.14 & 0.14 & 0.14 & 0.14 \\
\hline \multicolumn{6}{|l|}{ Calculated composition } \\
\hline Metabolizable energy (kcal/kg) & 2900 & 2900 & 2900 & 2900 & 2900 \\
\hline Crude protein & 20.00 & 20.00 & 20.000 & 20.00 & 20.00 \\
\hline Calcium & 2.50 & 2.50 & 2.50 & 2.50 & 2.50 \\
\hline Available phosphorous & 0.40 & 0.40 & 0.40 & 0.40 & 0.40 \\
\hline Sodium & 0.15 & 0.15 & 0.15 & 0.15 & 0.15 \\
\hline Methionine & 0.45 & 0.45 & 0.45 & 0.45 & 0.45 \\
\hline \multicolumn{6}{|l|}{ Analyzed value } \\
\hline Silicon (mg/kg) & 42 & 220 & 455 & 918 & 1842 \\
\hline
\end{tabular}

${ }^{a}$ The vitamin-mineral premix provided the following quantities per $\mathrm{kg}$ of diet: vitamin $\mathrm{A}, 9000 \mathrm{IU}$; vitamin $\mathrm{D}_{3}, 2000 \mathrm{IU}$; vitamin $\mathrm{E}$, $18 \mathrm{IU}$; vitamin $\mathrm{K}_{3}, 2 \mathrm{mg}$; vitamin $\mathrm{B}_{1}, 1.8 \mathrm{mg}$; vitamin $\mathrm{B}_{2}, 6.6 \mathrm{mg}$; vitamin $\mathrm{B}_{3}, 10 \mathrm{mg}$; vitamin $\mathrm{B}_{5}, 30 \mathrm{mg}$; vitamin $\mathrm{B}_{6}, 3 \mathrm{mg}$; vitamin $\mathrm{B}_{9}, 1 \mathrm{mg}$; vitamin $\mathrm{B}_{12}, 0.015 \mathrm{mg}$; biotin, $0.1 \mathrm{mg}$; choline chloride, $250 \mathrm{mg}$; antioxidant, $100 \mathrm{mg}$; Mn, $100 \mathrm{mg}$; Zn, $84.7 \mathrm{mg}$; Fe, $50 \mathrm{mg} ; \mathrm{Cu}, 10 \mathrm{mg} ; \mathrm{I}, 1 \mathrm{mg} ; \mathrm{Se}$, $0.2 \mathrm{mg}$ 


\section{Sampling procedure}

Production performance was measured from 18 to 26 weeks of age. Egg production and egg weight were recorded daily for each replicate, and the cumulative average egg production and egg weight calculated weekly. The collected data (number of eggs and egg weight) were used to calculate egg mass per replicate (egg number in replicate $\times$ average egg weight). Feed intake was measured on a weekly basis. Data on feed intake and egg mass were used to calculate feed conversion ratio (FCR, feed intake/egg mass, g/g). All the eggs laid during the last 3 days of the experiment, were collected by replicate ( 24 eggs per treatment) and yolk weight, albumen weight, shell weight, $\mathrm{pH}$ of yolk and albumen were measured. Furthermore, egg yolk relative weights (EYRW), albumen relative weight (AlbRW) and eggshell relative weight (shellRW) were calculated. To measure $\mathrm{Ca}, \mathrm{P}$ and $\mathrm{Si}$ concentration of eggs, their contents (yolk and albumin) were mixed and stored at $-20{ }^{\circ} \mathrm{C}$ until further analysis. At the end of 26 weeks of age, access to feed was denied for a period of $10 \mathrm{~h}$ and blood samples were taken and the birds were sacrificed. The blood samples were transferred to heparinized tubes and centrifuged for $10 \mathrm{~min}$ at $3000 \mathrm{~g}$. The plasma was removed and refrigerated $\left(-20^{\circ} \mathrm{C}\right)$ until further analysis. After blood sampling, the birds were sacrificed, a portion of liver was obtained, fixed in $10 \%$ formalin, and transferred to the laboratory for histopathological study. Moreover, a portion of liver and right thigh bone inserted in plastic bags and stored at -20 until analysis for $\mathrm{Ca}, \mathrm{P}$, and $\mathrm{Si}$ contents.

\section{Laboratory analysis}

The activities of AST, LDH, and ALP in plasma were determined using a Jasco V-570 spectrophotometer (Jasco, Japan) as per the instructions of the corresponding reagent kit (Pars Azmun, Tehran, Iran). A representative sample of liver and egg contents from each pen was oven-dried at $70{ }^{\circ} \mathrm{C}$ for $24 \mathrm{~h}$, ground, and analyzed for mineral contents. The content of $\mathrm{Si}$ was determined by flame atomic absorption spectrophotometer (Phoenix-986, AA spectrophotometer, UK) after wet washing with concentrated hydrochloric acid (Pignalosa et al. 2001). The content of $\mathrm{Ca}$ was determined by the versenate complexometric titration method using ethylene diamine tetra acetic acid as indicator (AOAC 2000). The content of $\mathrm{P}$ was determined by the vanadium-molybdate method described by AOAC (2000). After removing any adhering tissue, thigh bones were fat extracted, and then analyzed for ash minerals (AOAC 2000) on a fat free dry basis. Bone $\mathrm{Ca}, \mathrm{P}$, and $\mathrm{Si}$ were determined as indicated in the mineral analysis of liver and egg contents. The liver samples were processed for histological examination according to Bancroft and Gamble M (2008). The tissues were processed for paraffin embedding, and sections $(3-4 \mu \mathrm{m})$ were stained with hematoxylin and eosin, and damaged tissue was evaluated using a light microscope.

\section{Statistical analysis}

The general linear model procedure of SAS software (SAS 2001) was used for analyzing the data in a completely randomized design model. The means of treatments were compared using Duncan's multiple range tests. Values of $P<0.05$ were considered statistically significant.

\section{Results}

The effect of different levels of $\mathrm{nSiO}_{2}$ on growth performance of laying quails during the 8-week study is shown in Table 2. Egg mass and egg weight of quails were increased by $\mathrm{nSiO}_{2}(4000 \mathrm{mg} / \mathrm{kg}$ of diet) supplementation and were reduced significantly under level of $500 \mathrm{mg} / \mathrm{kg} \mathrm{nSiO}{ }_{2}$ $(P<0.05)$. However, the feed intake, egg production and FCR of the laying quails were not affected by $\mathrm{nSiO}_{2}$ supplementation $(P>0.05)$.

No significant difference $(P>0.05)$ was observed for the albumen weight, egg yolk relative weight (EYRW), albumin relative weight (AlbRW) and eggshell relative weight (shellRW), $\mathrm{pH}$ of yolk and albumen of quails after 8 weeks feeding with $\mathrm{nSiO}_{2}$ supplementation (Table 3). However, there was a significant increase in the shell weight of quails fed diets containing $4000 \mathrm{mg} \mathrm{nSiO}{ }_{2}$ per $\mathrm{kg}$ of diet $(P<0.05)$. Moreover, yolk weigh significantly decreased in the birds fed diets supplemented with $500 \mathrm{mg}$ $\mathrm{nSiO}_{2}$ per $\mathrm{kg}$ of diet $(P<0.05)$.

The effect of different level of $\mathrm{nSiO}_{2}$ on bone, liver and egg minerals concentrations of laying quail is shown in Table 4. Supplemental $\mathrm{nSiO}_{2}$ increased bone ash and $\mathrm{Ca}$ concentration in the bone of quails fed diets containing $4000 \mathrm{mg} \mathrm{nSiO} 2$ per $\mathrm{kg}$ of diet $(P<0.05)$ and $\mathrm{Si}$ concentration of bone in quails fed diets containing 500, 1000 and $2000 \mathrm{mg} \mathrm{nSiO}{ }_{2}$ per $\mathrm{kg}$ of diet $(P<0.05)$. However, no significant effect was observed on $\mathrm{Si}, \mathrm{Ca}$, and $\mathrm{P}$ concentration in egg and liver samples $(P>0.05)$.

The effect of different level of $\mathrm{nSiO}_{2}$ on concentrations (U/L) of liver enzymes in plasma in laying quails is shown in Table 5. No significant effect of treatments was found on any liver enzymes in plasma $(P>0.05)$. No significant change in the liver tissue histopathology was found among the treatments (Fig. 1). 
Table 2 The effect of different levels of nanosilicon dioxide on performance of laying quails

\begin{tabular}{|c|c|c|c|c|c|c|c|}
\hline \multirow[t]{2}{*}{ Items } & \multicolumn{5}{|c|}{ Supplemented nanosilicon dioxide level $(\mathrm{mg} / \mathrm{kg})$} & \multirow[t]{2}{*}{ SEM } & \multirow[t]{2}{*}{$P$ values } \\
\hline & 0 & 500 & 1000 & 2000 & 4000 & & \\
\hline Feed intake (g/bird/day) & 33.13 & 32.28 & 34.19 & 33.66 & 34.40 & 0.84 & 0.42 \\
\hline Egg production $(\%)$ & 89.28 & 84.73 & 89.87 & 90.90 & 90.96 & 1.65 & 0.06 \\
\hline Egg weight (g) & $12.72^{\mathrm{bc}}$ & $12.32^{\mathrm{d}}$ & $12.78^{\mathrm{c}}$ & $12.85^{\mathrm{b}}$ & $13.27^{\mathrm{a}}$ & 0.09 & 0.0001 \\
\hline Egg mass (g/bird/day) & $11.35^{\mathrm{b}}$ & $10.47^{\mathrm{c}}$ & $11.37^{\mathrm{b}}$ & $11.83^{\mathrm{ab}}$ & $12.01^{\mathrm{a}}$ & $0 / 21$ & 0.0001 \\
\hline Feed conversion ratio (g feed/g egg) & 3.01 & 3.34 & 3.02 & 3.11 & 3.07 & 0.11 & 0.24 \\
\hline
\end{tabular}

${ }^{\mathrm{a}-\mathrm{d}}$ Means with same superscript in each row are not significantly different $S E M$ standard error of the means

Table 3 The effect of different levels of nanosilicon dioxide on egg quality of laying quails

\begin{tabular}{|c|c|c|c|c|c|c|c|}
\hline \multirow[t]{2}{*}{ Items } & \multicolumn{5}{|c|}{ Supplemented dietary nanosilicon dioxide $(\mathrm{mg} / \mathrm{kg})$} & \multirow[t]{2}{*}{ SEM } & \multirow[t]{2}{*}{$P$ values } \\
\hline & 0 & 500 & 1000 & 2000 & 4000 & & \\
\hline Yolk weight (g) & $3.78^{\mathrm{ab}}$ & $3.60^{\mathrm{c}}$ & $3.72^{\mathrm{bc}}$ & $3.90^{\mathrm{ab}}$ & $4.08^{\mathrm{a}}$ & 0.07 & 0.001 \\
\hline Albumen weight $(\mathrm{g})$ & 7.96 & 7.64 & 8.00 & 7.79 & 8.23 & 0.15 & 0.11 \\
\hline Shell weight $(\mathrm{g})$ & $1.03^{\mathrm{b}}$ & $1.00^{\mathrm{b}}$ & $1.02^{\mathrm{b}}$ & $1.02^{\mathrm{b}}$ & $1.10^{\mathrm{a}}$ & 0.01 & 0.002 \\
\hline $\mathrm{pH}$ of yolk & 5.95 & 5.86 & 5.88 & 5.91 & 5.87 & 0.02 & 0.07 \\
\hline $\mathrm{pH}$ of albumen & 9.07 & 9.05 & 9.05 & 9.12 & 9.02 & 0.04 & 0.78 \\
\hline
\end{tabular}

${ }^{\mathrm{a}, \mathrm{b}}$ Means with same superscript in each row are not significantly different

SEM standard error of the means

Table 4 The effect of different levels of nanosilicon dioxide on ash, calcium, phosphorus and silicon contents in bone, liver and egg of laying quails

\begin{tabular}{|c|c|c|c|c|c|c|c|}
\hline \multirow[t]{2}{*}{ Items } & \multicolumn{5}{|c|}{ Supplemented dietary nanosilicon dioxide $(\mathrm{mg} / \mathrm{kg})$} & \multirow[t]{2}{*}{ SEM } & \multirow[t]{2}{*}{$P$ values } \\
\hline & 0 & 500 & 1000 & 2000 & 4000 & & \\
\hline \multicolumn{8}{|l|}{ Bone } \\
\hline Ash $(\%)$ & $56.53^{\mathrm{b}^{*}}$ & $58.04^{\mathrm{b}}$ & $57.84^{\mathrm{b}}$ & $59.01^{\mathrm{b}}$ & $62.98^{\mathrm{a}}$ & 0.47 & 0.04 \\
\hline Calcium (\%) & $19.21^{\mathrm{bc}}$ & $19.43^{\text {bc }}$ & $18.85^{\mathrm{c}}$ & $20.43^{\mathrm{bc}}$ & $21.77^{\mathrm{a}}$ & 0.23 & 0.02 \\
\hline Phosphorus (\%) & 9.09 & 9.24 & 9.17 & 9.27 & 9.13 & 0.10 & 0.94 \\
\hline Silicon (ppm) & $1.87^{\mathrm{c}}$ & $11.78^{\mathrm{a}}$ & $10.51^{\mathrm{a}}$ & $7.94^{\mathrm{ab}}$ & $3.60^{\mathrm{bc}}$ & 1.41 & 0.01 \\
\hline \multicolumn{8}{|l|}{ Liver } \\
\hline Calcium $(\%)$ & 0.011 & 0.010 & 0.010 & 0.011 & 0.011 & 0.001 & 0.26 \\
\hline Phosphorus (\%) & 0.13 & 0.13 & 0.14 & 0.13 & 0.12 & 0.004 & 0.42 \\
\hline Silicon (ppm) & 15.89 & 16.52 & 15.93 & 13.95 & 10.21 & 2.15 & 0.84 \\
\hline \multicolumn{8}{|l|}{ Egg } \\
\hline Calcium (\%) & 0.015 & 0.015 & 0.013 & 0.013 & 0.015 & 0.003 & 0.18 \\
\hline Phosphorus (\%) & 0.79 & 0.76 & 0.78 & 0.73 & 0.81 & 0.02 & 0.88 \\
\hline Silicon (ppm) & 1.53 & 1.76 & 3.35 & 2.84 & 2.70 & 0.43 & 0.70 \\
\hline
\end{tabular}

*,a,b Means with same superscript in each row are not significantly different

SEM standard error of the means 
Table 5 The effect of different levels of nanosilicon dioxide on concentrations (U/L) of liver enzymes in plasma of laying quails

\begin{tabular}{lllllll}
\hline Items & \multicolumn{2}{l}{ Supplemented dietary nanosilicon dioxide $(\mathrm{mg} / \mathrm{kg})$} & \multicolumn{2}{c}{ SEM } & \\
\cline { 2 - 5 } & 0 & 500 & 1000 & 2000 & 4000 & \\
\hline ALP & 186.40 & 179.40 & 200.40 & 189.10 & 187.50 & 75.53 \\
ASAT & 166.56 & 192.20 & 181.72 & 195.37 & 204.06 & 19.20 \\
LDH & 317.45 & 278.65 & 207.97 & 349.19 & 283.46 & 68.42 \\
\hline
\end{tabular}

$A L P$ alkaline phosphatase, $A S T$ aspartate aminotransferase, $L D H$ lactate dehydrogenase, $S E M$ standard error of the means

\section{Discussion}

The results of the present study indicated that $\mathrm{nSiO}_{2}$ supplementation increased quails egg weight and egg mass. Based on our knowledge, there is no published report related to use of $\mathrm{nSiO}_{2}$ in laying birds. However, Tran et al. (2015) reported that in turkeys, supplementing diet with $0.02 \% \mathrm{SiO}_{2}$ significantly improved body weight gain and FCR. Moreover, it is reported that $100 \mathrm{mg} / \mathrm{kg} \mathrm{SiO}_{2}$ in the diet can improve growth rate in chickens (Carlisle 1972, 1976). An improvement in body weight gain could also be obtained with supplementation of $2500 \mathrm{mg} / \mathrm{kg} \mathrm{SiO}$ to diet of fattening chickens (Vanschoubroek and Vermeersch 1996). Although in the present study we did not measure $\mathrm{nSiO}_{2}$ agglomeration, however, it is reported that high levels of nanoparticles in the diet, increase the possibility of their agglomeration in the small intestine leading to reduced absorption of the nanoparticles into the body (Philbrook et al. 2011; Bergin and Witzmann 2013). SakaiKato et al. (2014) reported that following a reduction in the electrostatic repulsion between negatively charged silica particles, agglomeration can occur in the stomach due to its lower $\mathrm{pH}$ conditions and as a result of agglomeration, intestinal absorption of the particles reduced. Chen et al. (2006) reported that nanoparticles increased the retention time of feed particles in the gastrointestinal tract and decreased intestinal emptying rate, and in turn improve nutrients absorption by intestinal absorptive cells. Moreover, Safaeikatouli et al. (2012), showed that silicate minerals make a temporary link with nutrient, decreases gastrointestinal transmission rate and therefore subject nutrients to further digestion which finally increases their absorption. As mentioned above, it is strongly possible that $\mathrm{nSiO}_{2}$ agglomeration occurred in the small intestine of laying quails fed diets containing $4000 \mathrm{mg} / \mathrm{kg}$ which reduced their absorption and hence leading link with digesta nutrients and finally resulted in a significant reduction of $\mathrm{nSiO}_{2}$ absorption in the small intestine. However in the birds treated with diets containing 1000 and $2000 \mathrm{mg} / \mathrm{kg} \mathrm{nSiO}{ }_{2}$ compared to the control group, it seems that agglomeration was not enough to decrease intestinal transmission rate and increase nutrients absorptions.

On the other hand, there was a significant reduction in the egg weight of the quails fed diets supplemented with $500 \mathrm{mg} / \mathrm{kg} \mathrm{nSiO}_{2}$, which can be due to negative effects of $\mathrm{nSiO}_{2}$ on very low density lipoprotein (VLDL) as one of the major yolk-forming components. This hypothesis is strengthened by Peluso and Schheeman (1994), who reported that plasma very low density protein (VLDL), and low density lipoprotein (LDL) concentrations reduced with inclusion of silicates in the diet of rats. One of the most important compounds for VLDL production in the liver is cholesterol. Moreover, cholesterol is a substrate for the synthesis of bile acids (Bravo and Cantafora 1990) and previous studies showed that interaction between $\mathrm{Si}$ and bile acids in the intestine likely affects liver cholesterol homeostasis. Peluso and Schheeman (1994) showed that Si dioxide could increase fecal cholic acids excretion, which finally inhibits cholesterol biosynthesis through inhibition of 3-hydroxy-3-methylglutaryl coenzyme A reductase. Therefore, reduction of vitellogenesis due to reduced VLDL biosynthesis (specific to production of egg-yolk) could be a reason for the reduced yolk weight and egg weights in birds treated with $500 \mathrm{mg} / \mathrm{kg} \mathrm{nSiO}$.

Although there is no previous study reported the effect of $\mathrm{Si}$ on eggshell formation in birds. However, it is demonstrated that $\mathrm{Si}$ has a significant effect on the bone matrix formation and bone calcification (Carlisle 1986, 1988). In our present study, there was a significant improvement in the eggshell weight of laying quails fed diets supplemented with $4000 \mathrm{mg} / \mathrm{kg} \mathrm{nSiO}{ }_{2}$. Due to important role of stored excess calcium in the bone for eggshell formation in laying birds, it is likely that dietary $\mathrm{nSiO}_{2}$ improved eggshell weight of laying quails via improving bone calcium reserve. Furthermore, it is likely that due to temporary link of $\mathrm{Si}$ with dietary calcium (Safaeikatouli et al. 2012), the amount of available calcium in the digestive tract during the period of eggshell formation increased and hence, improved eggshell thickness in the quails fed diets containing $4000 \mathrm{mg} \mathrm{nSiO} / 2 / \mathrm{kg}$ (Farmer et al. 1986). 
Fig. 1 Photomicrographs (optical microscopy) of hematoxylin and eosin-stained laying quail's liver sections from different treatments. a control; b contains $500 \mathrm{mg} / \mathrm{kg}$ nanosilicon dioxide; c contains $1000 \mathrm{mg} / \mathrm{kg}$ nanosilicon dioxide; $\mathbf{D}$ contains $2000 \mathrm{mg} / \mathrm{kg}$ nanosilicon dioxide; $\mathbf{E}$ contains $4000 \mathrm{mg} / \mathrm{kg}$ nanosilicon dioxide

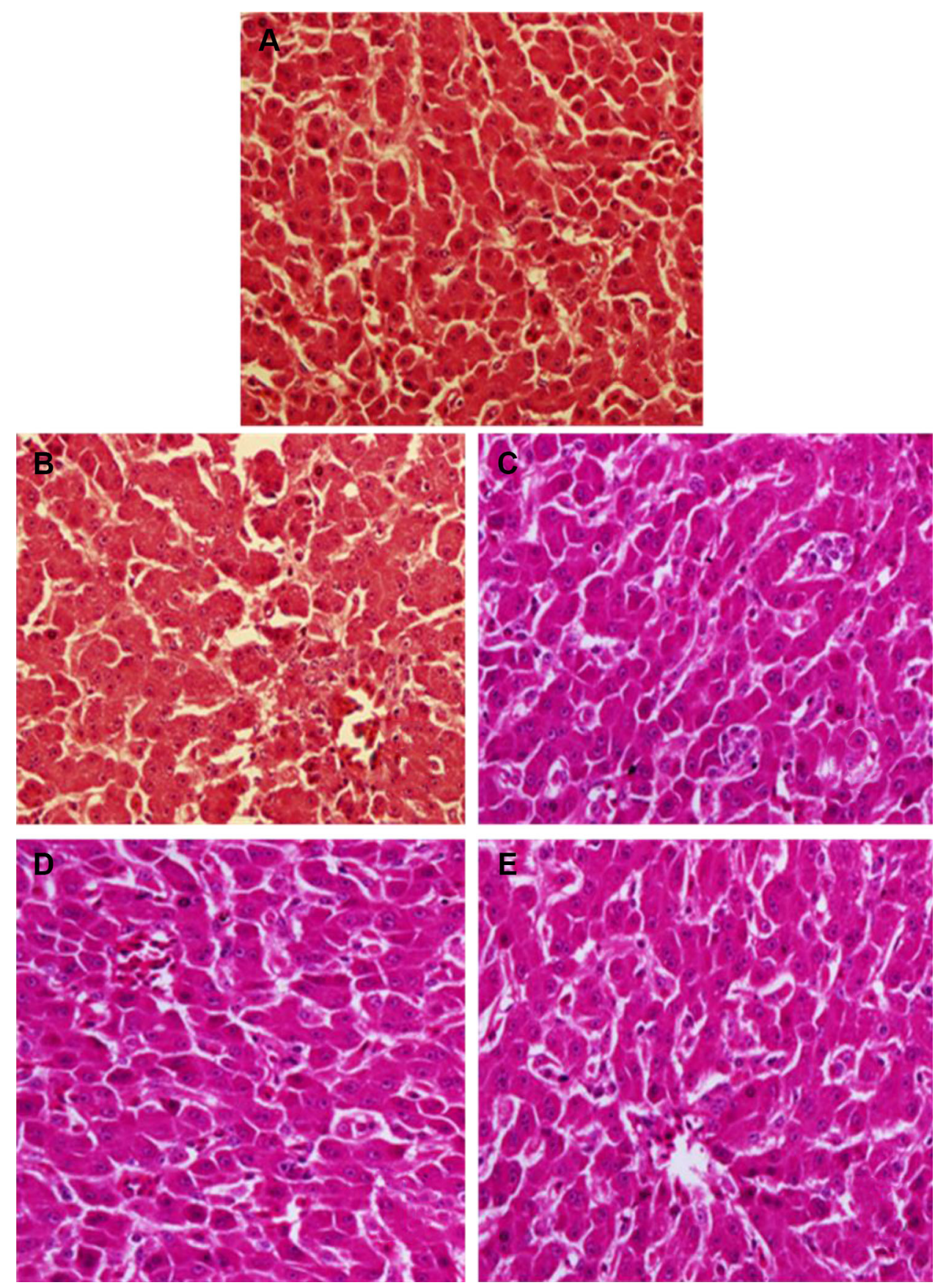

In the present study, an increase in bone ash content and $\mathrm{Ca}$ concentration of the bone was observed in laying quails fed $4000 \mathrm{mg} / \mathrm{kg} \mathrm{nSiO} 2$. As previously mentioned, agglomeration of Si nanoparticles at $4000 \mathrm{mg} / \mathrm{kg}$ of dietary $\mathrm{nSiO}_{2}$ leading to an increase in nutrients absorption (e.g. $\mathrm{Ca}$ ) in the small intestine. It is reported that $\mathrm{Si}$ particles are indestructible and burying them into the collagen tissue of the skeleton is the final solution (Pernis 2004). Hence, this could be an explanation for the increased concentration of
Si in the bone. Carlisle (1976) showed that percent of bone ash was not affected by $\mathrm{Si}$ supplemented diet. Our results were in concordance with Elliot and Edwards (1991) who reported that dietary Si supplementation has no effect on improvement and development of skeleton in broiler chickens.

Plasma biochemical parameters are the main tools for assessment of health in many species and are used as markers of disease or disorders in organs such as liver, 
kidneys, and biliary tract (Tran et al. 2015). In the present study, no effects of treatments were observed on plasma parameters. Investigating the liver histopathology, hematoxylin and eosin staining showed no significant changes between treatments. In whole treatments, normal liver cells with red cytoplasm indicating active cells surrounded the central vein of the liver lobule showed the lack of damage in liver tissue in treated birds. Lack of histological lesions in the present study indicated the very low absorption of $\mathrm{nSiO}_{2}$. Therefore, it is strongly possible that agglomeration of $\mathrm{Si}$ nanoparticles in the small intestine reduced its transfer to the liver. This assumption is supported by no significant effects of $\mathrm{nSiO}_{2}$ on $\mathrm{Si}$ concentration in liver of birds.

\section{Conclusions}

In conclusion, supplementation of the laying quail's diet with $\mathrm{nSiO}_{2}$ could improve bone density and performance of laying quails. In conclusion, supplementation the laying quail's diet with $\mathrm{nSiO}_{2}$ could improve performance, egg shell weight and bone density of laying quails. According to the present study, it seems that supplementation of laying quail's diet with $4000 \mathrm{mg} / \mathrm{kg} \mathrm{nSiO}_{2}$ resulted in an optimal supply of necessary nutrients for egg weight via stimulation of the gastrointestinal tract; therefore the egg weight was increased.

Acknowledgements This work supported by the University of Kurdistan.

Open Access This article is distributed under the terms of the Creative Commons Attribution 4.0 International License (http:// creativecommons.org/licenses/by/4.0/), which permits unrestricted use, distribution, and reproduction in any medium, provided you give appropriate credit to the original author(s) and the source, provide a link to the Creative Commons license, and indicate if changes were made.

\section{References}

A.O.A.C (2000) Official methods of analysis, 17th edn. Association of Official Analytical Chemist, Virginia

Bancroft JD, Gamble M (2008) Theory and practice of histological techniques, 6th edn. Elsevier, Philadelphia

Bergin IL, Witzmann FA (2013) Nanoparticle toxicity by the gastrointestinal route: evidence and knowledge gaps. Int $\mathrm{J}$ Biomed Nanosci Nanotechnol 3(1-2):163-210. doi:10.1504/ IJBNN.2013.054515

Bodak E, Dobrzanski Z, Trziszka T (1997) Biofunction of silicon and its role in animal production. Med Weter 53(6):316-322

Bravo E, Cantafora A (1990) Hepatic uptake and processing of free cholesterol from different lipoproteins with and without sodium taurocholate administration. An in vivo study in the rat.
Biochimica Biophysica Acta (BBA)-Lipids Lipid Metabol 1045(1):74-80

Carlisle EM (1972) Silicon: an essential element for the chick. Science 178:619-621

Carlisle EM (1976) In vivo requirement for silicon in articular cartilage and connective tissue formation in the chick. J Nutr 106(4):478-484

Carlisle EM (1981) Silicon: a requirement in bone formation independent of vitamin D1. Calcif Tissue Int 33(1):27-34

Carlisle EM (1986) Silicon as an essential trace element in animal nutrition. Ciba Found Symp 121-Silicon Biochem 123-139

Carlisle EM (1988) Silicon as a trace nutrient. Sci Total Environ 73(1):95-106

Chen H, Weiss J, Shahidi F (2006) Nanotechnology in nutraceuticals and functional foods. Food Technol 3:30-36

Elliot MA, Edwards HM Jr (1991) Comparison of the effects of synthetic and natural zeolite on laying hen and broiler chicken performance. Poult Sci 70(10):2115-2130

Farmer M, Roland DA Sr, Clark AJ (1986) Influence of dietary calcium on bone calcium utilization. Poult Sci 65:337-344

Jugdaohsingh R (2007) Silicon and bone health. J Nutr Health Aging 11(2):99

Maynard AD, Kuempel ED (2005) Airborne nanostructured particles and occupational health. J Nanopart Res 7:587-614

Nielsen FH, Sandstead HH (1974) Are nickel, vanadium, silicon, fluorine, and tin essential for man? A review. Am J Clin Nutr 27(5):515-520

Peluso MR, Schheeman BO (1994) A food-grade silicon dioxide is hypocholesterolemic in the diet of cholesterol-fed rats. J Nutr 124(6):853-860

Pernis B (2004) Silica and the immune system. Acta Biomed 76:38-44

Philbrook NA, Walker VK, Afrooz AN, Saleh NB, Winn LM (2011) Investigating the effects of functionalized carbon nanotubes on reproduction and development in Drosophila melanogaster and CD-1 mice. Reprod Toxicol 32(4):442-448

Pignalosa G, Cabrera N, Mollo A, Portillo I, Rouco V, Vázquez L (2001) Silicon determination in Portland cement by fluoride generation, using flame atomic absorption spectrometry. Spectrochim Acta Part B 56(10):1995-1999

Price CT, Koval KJ, Langford JR (2013) Silicon: a review of its potential role in the prevention and treatment of postmenopausal osteoporosis. Int J Endocrinol 2013:316783. doi:10.1155/2013/ 316783

Rabon HW Jr, Roland DA Sr, Bryant MM, Smith RC, Barnes DG, Laurent SM (1995) Absorption of silicon and aluminum by hens fed sodium zeolite A with various levels of dietary cholecalciferol. Poult Sci 74(2):352-359

Sadf Aaskh SSfca Institute (2001) SAS/STAT user, guide. Release Version 9.1. SAS Institute Inc., Cary

Safaeikatouli M, Boldaji F, Dastar B, Hassani S (2012) The effect of dietary silicate minerals supplementation on apparent ileal digestibility of energy and protein in broiler chickens. Int $\mathbf{J}$ Agric Biol 14:299-302

Sakai-Kato K, Hidaka M, Un K, Kawanishi T, Okuda H (2014) Physicochemical properties and in vitro intestinal permeability properties and intestinal cell toxicity of silica particles, performed in simulated gastrointestinal fluids. Biochimica Biophysica Acta 1840(3):1171-1180

Santurio JM (1999) Effect of sodium bentonite on the performance and blood variables of broiler chickens intoxicated with aflatoxins. Br Poult Sci 40(1):115-119

Sun L, Li Y, Liu X, Jin M, Zhang L, Du Z, Guo C, Huang P, Sun Z (2011) Cytotoxicity and mitochondrial damage caused by silica nanoparticles. Toxicol Vitro 25(8):1619-1620

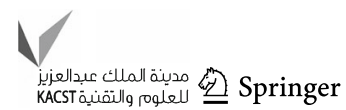


Tauqir NA, Sultan GI, Nawaz H (2001) Effect of different levels of bentonite with varying energy levels on the performance of broilers. Int J Agric Biol 3:85-88

Tran ST, Bowman ME, Smith TK (2015) Effects of a silica-based feed supplement on performance, health, and litter quality of growing turkeys. Poult Sci 94(8):1902-1908. doi:10.3382/ps/ pev15

Vanschoubroek F, Vermeersch G (1996) The effect of mixing silica grit in the diet of fattening chickens on weight gain and efficiency of feed conversion. Vlaams Diergeneeskd Tijdschr 35:557-565

\section{Publisher's Note}

Springer Nature remains neutral with regard to jurisdictional claims in published maps and institutional affiliations. 